\title{
INSIGHTS FROM THE ASSOCIATION OF SARS-CoV S-PROTEIN WITH ITS RECEPTOR, ACE2
}

\author{
Wenhui Li, Hyeryun Choe, and Michael Farzan*
}

\section{INTRODUCTION}

Angiotensin-converting enzyme 2 (ACE2) is the cellular receptor of the coronavirus (SARS-CoV) that is the etiological agent of severe acute respiratory syndrome (SARS). Biochemical and functional studies of animal ACE2 and of the SARS-CoV spike (S) protein from SARS-CoV isolated from potential sources of SARS-CoV shed some light on the origin of the virus and perhaps the severity of disease caused in 2002-2003.

\section{THE EMERGENCE OF SARS CORONAVIRUS}

Severe acute respiratory syndrome (SARS) was first described in November 2002, when inhabitants of Guangdong Province, China, presented with an influenza-like illness that began with headache, myalgia, and fever, often followed by acute atypical pneumonia, respiratory failure, and death. The outbreak spread over Asia, and to Europe and North America. A total of 8,096 cases were recorded, of which $774(9.6 \%)$ died. ${ }^{1-5}$ The etiological agent of SARS was identified as a novel coronavirus, SARS-CoV. ${ }^{6-10}$ This 2002-2003 SARS-CoV epidemic strain was successfully contained by conventional public health measures by July $2003 .^{11,12}$

SARS-CoV reemerged in Guangdong Province in the winter of 2003-2004, when it infected four individuals, all of whom recovered. ${ }^{13-15}$ No subsequent human-to-human transmission was observed in these latter cases. The infections in 2002-2003 and 20032004 were unlikely to be the first instances of SARS-CoV transmission to humans; almost 2\% (17 of 938) of serum samples collected in 2001 from one Hong Kong cohort recognized and neutralized SARS-CoV. ${ }^{16}$ Additional SARS cases resulted from accidental laboratory infections in 2003 and 2004. ${ }^{17,18}$

Exotic animals from the Guandong marketplace are likely to have been the immediate origin of SARS-CoV that infected humans in winters of both 2002-2003 and

\footnotetext{
*Wenhui Li, Michael Farzan, Harvard Medical School, Southborough, Massachusetts. Hyeryun Choe, Harvard
} Medical School, Boston, Massachusetts. 
2003-2004. Marketplace Himalayan palm civets (Paguma larvata) and raccoon dogs (Nyctereutes procyonoides) harbored viruses highly similar to SARS-CoV. ${ }^{19}$ Palm civets are of special interest because virus could be isolated from most marketplace civets, and SARS-CoV can persist in palm civets for weeks. ${ }^{20}$ Moreover, the sporadic infections observed in 2003-2004 were associated with restaurants in which palm civet meat was prepared and consumed. ${ }^{13,14}$ Additionally, culling of palm civets dramatically reduced the number of infected animals in the Guandong marketplace and may be responsible for the absence of virus in humans after the winter of 2003-2004. ${ }^{12,21}$ Finally, functional studies of the viral receptor, described below, also support a critical role for palm civets in transmitting virus to humans. ${ }^{22}$

Although the palm civet is likely to have been the immediate source of virus found in humans, evidence suggests that they served as a conduit for virus from another reservoir or precursor host. For example, although SARS anti-sera and virus was overwhelmingly present in marketplace palm civets in Guangdong, the vast majority of civets on farms and in the wild were found free of infection. ${ }^{23-25}$ Further, analysis of the rates of coding changes in the genomes of viruses isolated from palm civets suggest that the genome is not at equilibrium in the palm civet host. ${ }^{14,23}$ Recently, SARS-CoV-like viruses have been isolated from several bat species, predominately horseshoe bats (genus Rhinolophus) ${ }^{26,}{ }^{27}$ The genetic diversity of this virus in bat hosts, and the absence of overt disease, is consistent with a role for bats as a reservoir for SARS-CoV. However, as described below, substantial genetic changes in the spike (S) protein of bat SARS-CoV are likely necessary for this virus to infect humans.

\section{CORONAVIRUS S PROTEINS AND THEIR RECEPTORS}

Three distinct genetic and serological groups of coronaviruses have been defined. ${ }^{28,} 29$ Coronaviruses from groups 1 and 2 are known to cause disease in humans. ${ }^{30}$ Human coronavirus 229E (HCoV-229E), a group 1 virus, and human coronavirus OC43 (HCoVOC43), a group 2 virus, cause mild upper respiratory infections that result in self-resolving common colds in otherwise healthy individuals. ${ }^{29,}{ }^{30}$ Human coronavirus NL63 (HCoVNL63; also referred to as $\mathrm{HCoV}-\mathrm{NH}$ and $\mathrm{HCoV}-\mathrm{NL}$ ) has recently been identified as a group 1 virus causing conjunctivitis, croup, and sometimes serious respiratory infections in children. ${ }^{31-33}$ HCoV-NL63 is also notable for its use of the SARS-CoV cellular receptor ACE2 to infect cells. ${ }^{34}$ Another group 2 coronavirus (HCoV-HKU1) was recently isolated from a 71-year old man with pneumonia. ${ }^{35}$ SARS-CoV and SARS-CoV-like viruses found in animals also cluster with group 2 viruses, although they are outliers of group 2 and have been also described as group 4 , or, more recently, group 2 b viruses. ${ }^{36-38}$

Several coronavirus cell-surface receptors have been identified. Aminopeptidase N (APN, CD13) was shown to be the receptor for canine coronavirus, feline infectious peritonitis virus, $\mathrm{HCoV}-229 \mathrm{E}$, porcine epidemic diarrhea virus, and transmissible gastroenteritis virus, all of which are group 1 coronaviruses. ${ }^{39,}{ }^{40}$ Members of the pleiotropic family of carcinoembryonic antigen-cell adhesion molecules (CEACAMs) were identified as receptors for the group 2 pathogen murine hepatitis virus, ${ }^{41-43}$ whereas bovine group 2 coronaviruses bind to 9 - $O$-acetylated sialic acids. ${ }^{44}$ In 2003 , ACE2 was identified as a functional cellular for SARS-CoV. ${ }^{45}$ The role of ACE2 in HCoV-NL63 
infection was demonstrated after isolation and characterization of this recently described group 1 coronavirus. $^{34}$

\section{ACE2, THE SARS-CoV RECEPTOR}

ACE2 was identified as a functional receptor for SARS-CoV using a direct biochemical approach. ${ }^{45}$ The $\mathrm{S} 1$ region of the SARS-CoV $\mathrm{S}$ protein was used to precipitate ACE2 from Vero E6 cells, an African green monkey kidney cell line previously shown to support efficient viral replication. Robust syncytia formed between HEK 293T cells expressing the S protein and those over-expressing ACE2. Transfection of cell lines with ACE2 rendered them permissive to infection with SARS-CoV and with retroviruses pseudotyped with $\mathrm{S}$ protein. ${ }^{45,}{ }^{46}$ Anti-ACE2 antisera, but not identically prepared anti-ACE1 sera, blocked replication of SARS-CoV, as did a soluble form of ACE2.

Many lines of evidence further implicate ACE2 as the principal receptor utilized in vivo by SARS-CoV. ACE2 is expressed in the lung and in the gastrointestinal tract, the major sites of replication of the virus. ${ }^{47-50}$ The efficiency of infection in humans, mice, rats, and palm civets correlates with the ability of the ACE2 of each species to support viral replication. ${ }^{20,22,51-53}$ ACE2 binds $\mathrm{S}$ protein specifically, with approximately $2 \mathrm{nM}$ affinity. ${ }^{54}$ Although many cell lines do not express ACE2, all cell lines shown to support efficient SARS-CoV infection express this receptor. ${ }^{55,56}$ The ACE2-binding region of the $\mathrm{S}$ protein raises a protective neutralizing antibody response in mice, and anti-S-protein antibodies that block ACE2 association protect mice and hamsters against infection. ${ }^{57-60}$ Finally, little or no viral replication is observed in $\mathrm{ACE} 2^{-/-}$mice. ${ }^{61}$ Additional factors may also contribute to the efficiency of infection. DC-SIGNR (L-SIGN, CD209L), DC-SIGN (CD209), L-SECTIN have been shown to enhance infection of ACE2-expressing cells, ${ }^{62-65}$ these proteins do not appear to mediate efficient infection in the absence of ACE2. ${ }^{63,64}$

ACE2 is a type I transmembrane protein with a single metalloprotease active site with a HEXXH zinc binding motif. ${ }^{66,67}$ The enzyme has been shown to cleave a variety of regulatory peptides in vitro, among them angiotensin I and II, des-Arg-bradykinin, kinetensin, and neurotensin. ${ }^{66,68}$ Some cleavage products have been shown to be potent vasodilators with antidiuretic effects. This finding suggests that ACE2 counterbalances the actions of ACE1, which mediates vasoconstriction. ${ }^{69}$ Furthermore, targeted disruption of ACE2 in mice resulted in severe cardiac contractility defects. ${ }^{70}$ The enzymatic activity of ACE2 does not contribute its ability to mediate fusion and viral entry, and small molecule inhibitors that block catalysis do not inhibit SARS-CoV infection. ${ }^{22}$ However, ACE2 proteolysis has been implicated in SARS pathogenesis, and in acute respiratory distress syndrome (ARDS) caused by other viruses. ${ }^{61,71}$ These studies also demonstrated that SARS-CoV S protein can downregulate pulmonary ACE2, and that soluble ACE2 can protect mice from lung injury in a model of ARDS.

\section{THE SARS-COV RECEPTOR-BINDING DOMAIN}

Discrete, independently folded, receptor-binding domains (RBDs) of the S proteins of several coronaviruses have been described. ${ }^{72-77}$ The first 330 amino acids of the 769residue $\mathrm{S} 1$ subunit of the murine hepatitis virus $\mathrm{S}$ protein is sufficient to bind its receptor, 
CEACAM1. $^{72}$ A very different region of the S1 domain of HCoV-229E, between residues 407 and 547, is sufficient to associate with CD13. ${ }^{73,}{ }^{74}$ A 192-amino-acid fragment of the SARS-CoV S1 domain, residues 319-510, binds human ACE2 with greater efficiency than does the full-length S1 domain. ${ }^{75-77}$ The RBDs of these coronaviruses are found in distinct regions of the primary structure of the S protein. This pattern may suggest that coronavirus $S$ proteins are adapted for easy acquisition of novel binding domains, or for rapid shifts in receptor usage.

The crystal structure of the SARS-CoV RBD is consistent with this speculative possibility. ${ }^{78}$ The RBD contains two subdomains: a core and an extended loop. The core is a five-stranded, anti-parallel $\beta$-sheet, with three short connecting $\alpha$-helices. The loop, residues $424-494$, termed the receptor-binding motif (RBM), is the only domain that contacts ACE2 directly. Although the RBD core domain is homologous with similar regions of other group 2 coronaviruses, the RBM is unique to SARS-CoV. Some evidence supports the suggestion that the RBM has been acquired from another coronavirus, perhaps a group 1 virus relative of HCoV-NL63. As indicated, HCoV-NL63 also enters cells through ACE2, ${ }^{34}$ and its extended RBD region includes a stretch of residues with weak homology to the SARS-CoV RBM (unpublished observations).

Moreover, the recently described SARS-CoV-like viruses isolated from bats lack this stretch of residues, including those residues directly contacting ACE2. ${ }^{26,27,78}$ The absence of these RBM residues is consistent with the inability of these viruses to grow on tissue culture cells permissive for SARS-CoV. ${ }^{26,27}$ If indeed bats are reservoir animals for a SARS-CoV predecessor, acquisition of this ACE2-binding region is likely to have been a critical event in the evolution of the virus. According to this scenario, the virus found in bats utilizes another receptor. A recombination event, perhaps with a group 1 virus similar to HCoV-NL63, occurring in bats, palm civets or another host, may have given rise to SARS-CoV.

\section{INSIGHTS FROM ANIMAL ACE2 AND ANIMAL-DERIVED VIRAL ISOLATES}

The ability of the ACE2 proteins of mice, rats, and palm civets to support SARS$\mathrm{CoV}$ infection has been compared with that of human ACE2. ${ }^{22,}{ }^{51}$ Compared with cells expressing human receptor, SARS-CoV infection was less efficient in cells expressing murine ACE2. Infection was nearly absent in those expressing rat ACE2. Consistent with a role for palm civets in transmitting virus, palm civet ACE2 supported SARS-CoV infection as efficiently as human ACE2. These results correlated with affinity of each of these receptors for the $\mathrm{S}$ protein and its $\mathrm{RBD}{ }^{22,}{ }^{51}$ Chimeras between human and rat ACE2 receptors were used to identify the S-protein binding site on ACE2. ${ }^{22}$ Mutation of four rat ACE2 residues (82-84 and 353) to their human equivalents converted rat ACE2 into an efficient SARS-CoV receptor. Residues 82-84 comprise a glycosylation site on the rat receptor that is not present on mouse, palm civet, or human receptor. Residue 353 is a histidine in mouse and rat receptors, and a lysine in palm civet and human ACE2. Strikingly, alteration of histidine 353 of mouse ACE2 to the human lysine results in a receptor that supports infection as efficiently as human ACE2 (Wenhui Li, unpublished observation). Alterations of additional residues along the first helix of human ACE2 (lysine 31 and tyrosine 41) to alanine interfered with S-protein-mediated infection and 
RBD association. Collectively these data localize the S-protein-binding region to the membrane-distal lobe of the cleft that contains the catalytic site of ACE2. ${ }^{22,78}$

Three S proteins of distinct origins have been compared for their ability to use human and palm civet ACE2. ${ }^{22,79,80}$ The first, TOR2, was isolated during the 2002-2003 epidemic. ${ }^{81}$ The second, denoted as GD03, was isolated from the sporadic infections in 2003-2004. ${ }^{82}$ The third, SZ3, was obtained from palm civets. ${ }^{19}$ Both SZ3 and, less expectedly, GD03 bound and utilized palm civet ACE2 much more efficiently than human ACE2. ${ }^{22}$ In contrast, TOR2 utilized both receptors efficiently. The efficiency with which virus from both human outbreaks utilized palm civet receptor is consistent with recent transfer of SARS-CoV from palm civets to humans. The lower efficiency with which GD03 utilized human ACE2 compared with TOR2 may in part account for the mildness of symptoms, and absence of subsequent transmission observed during the 2003-2004 infections. $^{13,14}$

The differences in these three S-proteins were also reflected in the ability of their RBDs to bind human and palm civet ACE2. Two amino acids, residues 479 and 487, largely determined the much greater efficiency with which the TOR2 RBD bound human ACE2. ${ }^{22,79}$ Residue 479 is an asparagine or serine in all $\mathrm{S}$ proteins isolated from humans, either during the 2002-2003 epidemic or during 2003-2004 infections. However most sequences isolated from palm civets or raccoon dogs encode a lysine at this position. This lysine is incompatible with human ACE2, but palm civet ACE2 can efficiently bind S proteins expressing either lysine or asparagine, without an apparent preference for either. ${ }^{22}$ Palm civets may therefore be an important intermediate in the transfer of SARS$\mathrm{CoV}$ to humans, permitting the emergence of viruses that express a small, uncharged amino-acids at S-protein residue 479.

Residue 487 is also of interest. Residues 487 is a threonine in all of the more than $100 \mathrm{~S}$ protein sequences obtained during the $2002-2003$ outbreak. $^{82}$ It is a serine in $\mathrm{S}$ proteins from viruses isolated during the mild 2003-2004 infections, and in all but one of the 20 or so S-proteins sequences obtained from palm civets and raccoon dogs. The relatively modest change of threonine in the TOR2 RBD to serine resulted in an approximately 20 -fold decrease in binding to human ACE2. ${ }^{22}$ A corresponding increase was observed when a threonine was introduced into the SZ3 RBD. A threonine at position 487 also substantially increased association with palm civet ACE2. Notably, the single palm-civet-derived $\mathrm{S}$ protein sequence that encoded a threonine at position 487 also encoded an asparagine at position 479 (Zhihong Hu, personal communication). The emergence of this rare combination of S-protein residues in palm civet-derived virus may have been necessary to generate a SARS-CoV that could efficiently transmit between humans. The infrequency of threonine 487 in animal-derived viruses may suggest that the receptor of the ultimate reservoir of SARS-CoV better utilizes a serine at this position.

The co-crystal of ACE2 with the SARS-CoV RBD clarifies these observations. ${ }^{78}$ TOR2 S-protein asparagine 479, most commonly a lysine in palm civet virus, interacts with a network of residues that include lysine 31 of human ACE2. Palm civet and murine ACE2 express small, uncharged residues at this position, presumably better accommodating an S-protein lysine. S-protein residue 487, a threonine in all epidemic SARS-CoV isolates, directly contacts critical ACE2 lysine 353. Interaction of the threonine methyl group with lysine 353 provides a clear explanation for the decrease in affinity for human and palm civet ACE2 when this threonine is altered to serine. 


\section{CONCLUSIONS}

Important questions remain. What receptor does bat SARS-CoV utilize? If bats are indeed a reservoir of SARS-CoV-like viruses, when and in which species did these viruses acquire an $\mathrm{S}$ protein capable of using palm civet and human ACE2? Did SARS$\mathrm{CoV}$ gain the use of ACE2 through recombination, and if so, with what transcript? Are changes in the $\mathrm{S}$ protein that enhanced human-to-human transmission a probable consequence of incubation in palm civets and other animals, or a unique event unlikely to recur? What other changes in other viral proteins were necessary for SARS-CoV to transmit efficiently among humans? Our experience with SARS has taught us much about zoonotic transmission and coronaviral evolution, and there is yet more to learn.

\section{REFERENCES}

1. J. S. Peiris, S. T. Lai, L. L. Poon, Y. Guan, L. Y. Yam, W. Lim, J. Nicholls, W. K. Yee, W. W. Yan, M. T. Cheung, V. C. Cheng, K. H. Chan, D. N. Tsang, R. W. Yung, T. K. Ng, and K. Y. Yuen, Coronavirus as a possible cause of severe acute respiratory syndrome, Lancet 361, 1319-1325 (2003).

2. I. T. Yu, Y. Li, T. W. Wong, W. Tam, A. T. Chan, J. H. Lee, D. Y. Leung, and T. Ho, Evidence of airborne transmission of the severe acute respiratory syndrome virus, N. Engl. J. Med. 350, 1731-1739 (2004).

3. N. Zhong, Y. Ding, Y. Mao, Q. Wang, G. Wang, D. Wang, Y. Cong, Q. Li, Y. Liu, L. Ruan, B. Chen, X. Du, Y. Yang, Z. Zhang, X. Zhang, J. Lin, J. Zheng, Q. Zhu, D. Ni, X. Xi, G. Zeng, D. Ma, C. Wang, W. Wang, B. Wang, J. Wang, D. Liu, X. Li, X. Liu, J. Chen, R. Chen, F. Min, P. Yang, Y. Zhang, H. Luo, Z. Lang, Y. Hu, A. Ni, W. Cao, J. Lei, S. Wang, Y. Wang, X. Tong, W. Liu, M. Zhu, W. Chen, X. Xhen, L. Lin, Y. Luo, J. Zhong, W. Weng, S. Peng, Z. Pan, R. Wang, J. Zuo, B. Liu, N. Zhang, J. Zhang, B. Zhang, L. Chen, P. Zhou, L. Jiang, E. Chao, L. Guo, X. Tan, and J. Pan, Consensus for the management of severe acute respiratory syndrome, Chin. Med. J. (Engl.) 116, 1603-1635 (2003).

4. N. Lee, D. Hui, A. Wu, P. Chan, P. Cameron, G. M. Joynt, A. Ahuja, M. Y. Yung, C. B. Leung, K. F. To, S. F. Lui, C. C. Szeto, S. Chung, and J. J. Sung, A major outbreak of severe acute respiratory syndrome in Hong Kong, N. Engl. J. Med. 348, 1986-1994 (2003).

5. J. D. Cherry, The chronology of the 2002-2003 SARS mini pandemic, Paediatr. Respir. Rev. 5, 262-269 (2004).

6. C. Drosten, S. Gunther, W. Preiser, S. van der Werf, H. R. Brodt, S. Becker, H. Rabenau, M. Panning, L. Kolesnikova, R. A. Fouchier, A. Berger, A. M. Burguiere, J. Cinatl, M. Eickmann, N. Escriou, K. Grywna, S. Kramme, J. C. Manuguerra, S. Muller, V. Rickerts, M. Sturmer, S. Vieth, H. D. Klenk, A. D. Osterhaus, H. Schmitz, and H. W. Doerr, Identification of a novel coronavirus in patients with severe acute respiratory syndrome, N. Engl. J. Med. 348, 1967-1976 (2003).

7. R. A. Fouchier, T. Kuiken, M. Schutten, G. van Amerongen, G. J. van Doornum, B. G. van den Hoogen, M. Peiris, W. Lim, K. Stohr, and A. D. Osterhaus, Aetiology: Koch's postulates fulfilled for SARS virus, Nature 423, 240 (2003).

8. T. G. Ksiazek, D. Erdman, C. S. Goldsmith, S. R. Zaki, T. Peret, S. Emery, S. Tong, C. Urbani, J. A. Comer, W. Lim, P. E. Rollin, S. F. Dowell, A. E. Ling, C. D. Humphrey, W. J. Shieh, J. Guarner, C. D. Paddock, P. Rota, B. Fields, J. DeRisi, J. Y. Yang, N. Cox, J. M. Hughes, J. W. LeDuc, W. J. Bellini, and L. J. Anderson, A novel coronavirus associated with severe acute respiratory syndrome, N. Engl. J. Med. 348, 1953-1966 (2003).

9. T. Kuiken, R. A. Fouchier, M. Schutten, G. F. Rimmelzwaan, G. van Amerongen, D. van Riel, J. D. Laman, T. de Jong, G. van Doornum, W. Lim, A. E. Ling, P. K. Chan, J. S. Tam, M. C. Zambon, R. Gopal, C. Drosten, S. van der Werf, N. Escriou, J. C. Manuguerra, K. Stohr, J. S. Peiris, and A. D. Osterhaus, Newly discovered coronavirus as the primary cause of severe acute respiratory syndrome, Lancet 362, 263-270 (2003).

10. N. S. Zhong, B. J. Zheng, Y. M. Li, Poon, Z. H. Xie, K. H. Chan, P. H. Li, S. Y. Tan, Q. Chang, J. P. Xie, X. Q. Liu, J. Xu, D. X. Li, K. Y. Yuen, Peiris, and Y. Guan, Epidemiology and cause of severe acute respiratory syndrome (SARS) in Guangdong, People's Republic of China, in February, 2003, Lancet 362, 1353-1358 (2003).

11. J. S. Peiris, Y. Guan, and K. Y. Yuen, Severe acute respiratory syndrome, Nat. Med. 10, S88-97 (2004). 
12. N. Zhong, Management and prevention of SARS in China, Philos. Trans. R. Soc. Lond. B Biol. Sci. 359, 1115-1116 (2004).

13. G. Liang, Q. Chen, J. Xu, Y. Liu, W. Lim, J. S. Peiris, L. J. Anderson, L. Ruan, H. Li, B. Kan, B. Di, P. Cheng, K. H. Chan, D. D. Erdman, S. Gu, X. Yan, W. Liang, D. Zhou, L. Haynes, S. Duan, X. Zhang, H. Zheng, Y. Gao, S. Tong, D. Li, L. Fang, P. Qin, and W. Xu, Laboratory diagnosis of four recent sporadic cases of community-acquired SARS, Guangdong Province, China, Emerg. Infect. Dis. 10, 1774-1781 (2004).

14. H. D. Song, C. C. Tu, G. W. Zhang, S. Y. Wang, K. Zheng, L. C. Lei, Q. X. Chen, Y. W. Gao, H. Q. Zhou, H. Xiang, H. J. Zheng, S. W. Chern, F. Cheng, C. M. Pan, H. Xuan, S. J. Chen, H. M. Luo, D. H. Zhou, Y. F. Liu, J. F. He, P. Z. Qin, L. H. Li, Y. Q. Ren, W. J. Liang, Y. D. Yu, L. Anderson, M. Wang, R. H. Xu, X. W. Wu, H. Y. Zheng, J. D. Chen, G. Liang, Y. Gao, M. Liao, L. Fang, L. Y. Jiang, H. Li, F. Chen, B. Di, L. J. He, J. Y. Lin, S. Tong, X. Kong, L. Du, P. Hao, H. Tang, A. Bernini, X. J. Yu, O. Spiga, Z. M. Guo, H. Y. Pan, W. Z. He, J. C. Manuguerra, A. Fontanet, A. Danchin, N. Niccolai, Y. X. Li, C. I. Wu, and G. P. Zhao, Cross-host evolution of severe acute respiratory syndrome coronavirus in palm civet and human, Proc. Natl. Acad. Sci. USA 102, 2430-2435 (2005).

15. F. Fleck, SARS virus returns to China as scientists race to find effective vaccine, Bull. World Health Organ. 82, 152-153 (2004)

16. B. J. Zheng, K. H. Wong, J. Zhou, K. L. Wong, B. W. Young, L. W. Lu, and S. S. Lee, SARS-related virus predating SARS outbreak, Hong Kong, Emerg. Infect. Dis. 10, 176-178 (2004).

17. D. Normile, Infectious diseases. Mounting lab accidents raise SARS fears, Science 304, 659-661 (2004).

18. P. L. Lim, A. Kurup, G. Gopalakrishna, K. P. Chan, C. W. Wong, L. C. Ng, S. Y. Se-Thoe, L. Oon, X. Bai, L. W. Stanton, Y. Ruan, L. D. Miller, V. B. Vega, L. James, P. L. Ooi, C. S. Kai, S. J. Olsen, B. Ang, and Y. S. Leo, Laboratory-acquired severe acute respiratory syndrome, N. Engl. J. Med. 350, 1740-1745 (2004).

19. Y. Guan, B. J. Zheng, Y. Q. He, X. L. Liu, Z. X. Zhuang, C. L. Cheung, S. W. Luo, P. H. Li, L. J. Zhang, Y. J. Guan, K. M. Butt, K. L. Wong, K. W. Chan, W. Lim, K. F. Shortridge, K. Y. Yuen, J. S. Peiris, and L. L. Poon, Isolation and characterization of viruses related to the SARS Coronavirus from animals in Southern China, Science 302, 276-278 (2003).

20. D. Wu, C. Tu, C. Xin, H. Xuan, Q. Meng, Y. Liu, Y. Yu, Y. Guan, Y. Jiang, X. Yin, G. Crameri, M. Wang, C. Li, S. Liu, M. Liao, L. Feng, H. Xiang, J. Sun, J. Chen, Y. Sun, S. Gu, N. Liu, D. Fu, B. T. Eaton, L. F. Wang, and $\mathrm{X}$. Kong, Civets are equally susceptible to experimental infection by two different severe acute respiratory syndrome coronavirus isolates, J. Virol. 79, 2620-2625 (2005).

21. M. Wang, H. Q. Jing, H. F. Xu, X. G. Jiang, B. Kan, Q. Y. Liu, K. L. Wan, B. Y. Cui, H. Zheng, Z. G. Cui, M. Y. Yan, W. L. Liang, H. X. Wang, X. B. Qi, Z. J. Li, M. C. Li, K. Chen, E. M. Zhang, S. Y. Zhang, R. Hai, D. Z. Yu, and J. G. Xu, Surveillance on severe acute respiratory syndrome associated coronavirus in animals at a live animal market of Guangzhou in 2004, Zhonghua Liu Xing Bing Xue Za Zhi 26, 84-87 (2005).

22. W. Li, C. Zhang, J. Sui, J. H. Kuhn, M. J. Moore, S. Luo, S. K. Wong, I. C. Huang, K. Xu, N. Vasilieva, A. Murakami, Y. He, W. A. Marasco, Y. Guan, H. Choe, and M. Farzan, Receptor and viral determinants of SARS-coronavirus adaptation to human ACE2, EMBO J. 24, 1634 (2005).

23. B. Kan, M. Wang, H. Jing, H. Xu, X. Jiang, M. Yan, W. Liang, H. Zheng, K. Wan, Q. Liu, B. Cui, Y. Xu, E. Zhang, H. Wang, J. Ye, G. Li, M. Li, Z. Cui, X. Qi, K. Chen, L. Du, K. Gao, Y.-T. Zhao, X.-Z. Zou, Y.-J. Feng, Y.-F. Gao, R. Hai, D. Yu, Y. Guan, and J. Xu, Molecular evolution analysis and geographic investigation of severe acute respiratory syndrome coronavirus-like virus in palm civets at an animal market and on farms, J. Virol. 79, 11892-11900 (2005).

24. C. Tu, G. Crameri, X. Kong, J. Chen, Y. Sun, M. Yu, H. Xiang, X. Xia, S. Liu, T. Ren, Y. Yu, B. T. Eaton, H. Xuan, and L. F. Wang, Antibodies to SARS coronavirus in civets, Emerg. Infect. Dis. 10, 2244-2248 (2004).

25. L. L. Poon, D. K. Chu, K. H. Chan, O. K. Wong, T. M. Ellis, Y. H. Leung, S. K. Lau, P. C. Woo, K. Y. Suen, K. Y. Yuen, Y. Guan, and J. S. Peiris, Identification of a novel coronavirus in bats, J. Virol. 79, 2001 2009 (2005).

26. W. Li, Z. Shi, M. Yu, W. Ren, C. Smith, J. H. Epstein, H. Wang, G. Crameri, Z. Hu, H. Zhang, J. Zhang, J. McEachern, H. Field, P. Daszak, B. T. Eaton, S. Zhang, and L. F. Wang, Bats are natural reservoirs of SARS-like coronaviruses, Science 310, 676-679 (2005).

27. S. K. Lau, P. C. Woo, K. S. Li, Y. Huang, H. W. Tsoi, B. H. Wong, S. S. Wong, S. Y. Leung, K. H. Chan, and K. Y. Yuen, Severe acute respiratory syndrome coronavirus-like virus in Chinese horseshoe bats, Proc. Natl. Acad. Sci. USA 102, 14040-14045 (2005).

28. J. M. Gonzalez, P. Gomez-Puertas, D. Cavanagh, A. E. Gorbalenya, and L. Enjuanes, A comparative sequence analysis to revise the current taxonomy of the family Coronaviridae, Arch. Virol. 148, 2207-2235 (2003). 
29. D. A. Brian and R. S. Baric, Coronavirus genome structure and replication, Curr. Top. Microbiol. Immunol. 287, 1-30 (2005)

30. K. McIntosh, Coronaviruses in the limelight, J. Infect. Dis. 191, 489-491 (2005).

31. F. Esper, C. Weibel, D. Ferguson, M. L. Landry, and J. S. Kahn, Evidence of a novel human coronavirus that is associated with respiratory tract disease in infants and young children, J. Infect. Dis. 191, 492-498 (2005).

32. R. A. Fouchier, N. G. Hartwig, T. M. Bestebroer, B. Niemeyer, J. C. de Jong, J. H. Simon, and A. D. Osterhaus, A previously undescribed coronavirus associated with respiratory disease in humans, Proc. Natl. Acad. Sci. USA 101, 6212-6216 (2004).

33. L. van der Hoek, K. Pyrc, M. F. Jebbink, W. Vermeulen-Oost, R. J. Berkhout, K. C. Wolthers, P. M. Wertheim-van Dillen, J. Kaandorp, J. Spaargaren, and B. Berkhout, Identification of a new human coronavirus, Nat. Med. 10, 368-373 (2004).

34. H. Hofmann, K. Pyrc, L. van der Hoek, M. Geier, B. Berkhout, and S. Pohlmann, Human coronavirus NL63 employs the severe acute respiratory syndrome coronavirus receptor for cellular entry, Proc. Natl. Acad. Sci. USA 102, 7988-7983 (2005).

35. P. C. Woo, S. K. Lau, C. M. Chu, K. H. Chan, H. W. Tsoi, Y. Huang, B. H. Wong, R. W. Poon, J. J. Cai, W. K. Luk, L. L. Poon, S. S. Wong, Y. Guan, J. S. Peiris, and K. Y. Yuen, Characterization and complete genome sequence of a novel coronavirus, coronavirus HKU1, from patients with pneumonia, J. Virol. 79, 884-895 (2005).

36. A. E. Gorbalenya, E. J. Snijder, and W. J. Spaan, Severe acute respiratory syndrome coronavirus phylogeny: toward consensus, J. Virol. 78, 7863-7866 (2004).

37. E. J. Snijder, P. J. Bredenbeek, J. C. Dobbe, V. Thiel, J. Ziebuhr, L. L. Poon, Y. Guan, M. Rozanov, W. J. Spaan, and A. E. Gorbalenya, Unique and conserved features of genome and proteome of SARScoronavirus, an early split-off from the coronavirus Group 2 lineage, J. Mol. Biol. 331, 991-1004 (2003).

38. A. J. Gibbs, M. J. Gibbs, and J. S. Armstrong, The phylogeny of SARS coronavirus, Arch. Virol. 149, 621624 (2004).

39. B. Delmas, J. Gelfi, R. L'Haridon, L. K. Vogel, H. Sjostrom, O. Noren, and H. Laude, Aminopeptidase N is a major receptor for the entero-pathogenic coronavirus TGEV, Nature 357, 417-420 (1992).

40. C. L. Yeager, R. A. Ashmun, R. K. Williams, C. B. Cardellichio, L. H. Shapiro, A. T. Look, and K. V. Holmes, Human aminopeptidase N is a receptor for human coronavirus 229E, Nature 357, 420-422 (1992).

41. G. S. Dveksler, C. W. Dieffenbach, C. B. Cardellichio, K. McCuaig, M. N. Pensiero, G. S. Jiang, N. Beauchemin, and K. V. Holmes, Several members of the mouse carcinoembryonic antigen-related glycoprotein family are functional receptors for the coronavirus mouse hepatitis virus-A59, J. Virol. 67, 1-8 (1993).

42. G. S. Dveksler, M. N. Pensiero, C. B. Cardellichio, R. K. Williams, G. S. Jiang, K. V. Holmes, and C. W. Dieffenbach, Cloning of the mouse hepatitis virus (MHV) receptor: expression in human and hamster cell lines confers susceptibility to MHV, J. Virol. 65, 6881-6891 (1991).

43. R. K. Williams, G. S. Jiang, and K. V. Holmes, Receptor for mouse hepatitis virus is a member of the carcinoembryonic antigen family of glycoproteins, Proc. Natl. Acad. Sci. USA 88, 5533-5536 (1991).

44. B. Schultze and G. Herrler, Bovine coronavirus uses N-acetyl-9-O-acetylneuraminic acid as a receptor determinant to initiate the infection of cultured cells, J. Gen. Virol. 73, 901-906 (1992).

45. W. Li, M. J. Moore, N. Vasilieva, J. Sui, S. K. Wong, M. A. Berne, M. Somasundaran, J. L. Sullivan, C. Luzeriaga, T. C. Greenough, H. Choe, and M. Farzan, Angiotensin-converting enzyme 2 is a functional receptor for the SARS coronavirus, Nature 426, 450-454 (2003).

46. M. J. Moore, T. Dorfman, W. Li, S. K. Wong, Y. Li, J. H. Kuhn, J. Coderre, N. Vasilieva, Z. Han, T. C. Greenough, M. Farzan, and H. Choe, Retroviruses pseudotyped with the severe acute respiratory syndrome coronavirus spike protein efficiently infect cells expressing angiotensin-converting enzyme 2, J. Virol. 78 , 10628-10635 (2004).

47. P. K. Chan, K. F. To, A. W. Lo, J. L. Cheung, I. Chu, F. W. Au, J. H. Tong, J. S. Tam, J. J. Sung, and H. K. $\mathrm{Ng}$, Persistent infection of SARS coronavirus in colonic cells in vitro, J. Med. Virol. 74, 1-7 (2004).

48. Y. Ding, L. He, Q. Zhang, Z. Huang, X. Che, J. Hou, H. Wang, H. Shen, L. Qiu, Z. Li, J. Geng, J. Cai, H. Han, X. Li, W. Kang, D. Weng, P. Liang, and S. Jiang, Organ distribution of severe acute respiratory syndrome (SARS) associated coronavirus (SARS-CoV) in SARS patients: implications for pathogenesis and virus transmission pathways, J. Pathol. 203, 622-630 (2004).

49. I. Hamming, W. Timens, M. L. Bulthuis, A. T. Lely, G. J. Navis, and H. van Goor, Tissue distribution of ACE2 protein, the functional receptor for SARS coronavirus. A first step in understanding SARS pathogenesis, J. Pathol. 203, 631-637 (2004).

50. D. Harmer, M. Gilbert, R. Borman, and K. L. Clark, Quantitative mRNA expression profiling of ACE 2, a novel homologue of angiotensin converting enzyme, FEBS Lett. 532, 107-110 (2002). 
51. W. Li, T. C. Greenough, M. J. Moore, N. Vasilieva, M. Somasundaran, J. L. Sullivan, M. Farzan, and H. Choe, Efficient replication of severe acute respiratory syndrome coronavirus in mouse cells is limited by murine Angiotensin-converting enzyme 2, J. Virol. 78, 11429-11433 (2004).

52. K. Subbarao, J. McAuliffe, L. Vogel, G. Fahle, S. Fischer, K. Tatti, M. Packard, W. J. Shieh, S. Zaki, and B. Murphy, Prior infection and passive transfer of neutralizing antibody prevent replication of severe acute respiratory syndrome coronavirus in the respiratory tract of mice, J. Virol. 78, 3572-3577 (2004).

53. D. E. Wentworth, L. Gillim-Ross, N. Espina, and K. A. Bernard, Mice susceptible to SARS coronavirus, Emerg. Infect. Dis. 10, 1293-1296 (2004).

54. J. Sui, W. Li, A. Murakami, A. Tamin, L. J. Matthews, S. K. Wong, M. J. Moore, A. St Clair Tallarico, M. Olurinde, H. Choe, L. J. Anderson, W. J. Bellini, M. Farzan, and W. A. Marasco, Potent neutralization of severe acute respiratory syndrome (SARS) coronavirus by a human mAb to S1 protein that blocks receptor association, Proc. Natl. Acad. Sci. USA 101, 2536-2541 (2004).

55. H. Hofmann, M. Geier, A. Marzi, M. Krumbiegel, M. Peipp, G. H. Fey, T. Gramberg, and S. Pohlmann, Susceptibility to SARS coronavirus S protein-driven infection correlates with expression of angiotensin converting enzyme 2 and infection can be blocked by soluble receptor, Biochem. Biophys. Res. Commun. 319, 1216-1221 (2004).

56. Y. Nie, P. Wang, X. Shi, G. Wang, J. Chen, A. Zheng, W. Wang, Z. Wang, X. Qu, M. Luo, L. Tan, X. Song, X. Yin, M. Ding, and H. Deng, Highly infectious SARS-CoV pseudotyped virus reveals the cell tropism and its correlation with receptor expression, Biochem. Biophys. Res. Commun. 321, 994-1000 (2004).

57. T. C. Greenough, G. J. Babcock, A. Roberts, H. J. Hernandez, W. D. Thomas, Jr., J. A. Coccia, R. F. Graziano, M. Srinivasan, I. Lowy, R. W. Finberg, K. Subbarao, L. Vogel, M. Somasundaran, K. Luzuriaga, J. L. Sullivan, and D. M. Ambrosino, Development and characterization of a severe acute respiratory syndrome-associated coronavirus-neutralizing human monoclonal antibody that provides effective immunoprophylaxis in mice, J. Infect. Dis. 191, 507-514 (2005).

58. J. Sui, W. Li, A. Roberts, L. J. Matthews, A. Murakami, L. Vogel, S. K. Wong, K. Subbarao, M. Farzan, and W. A. Marasco, Evaluation of human mAb 80R in immunoprophylaxis of SARS by an animal study, epitope mapping and analysis of spike variants, J. Virol. in press, 2005.

59. Y. He, H. Lu, P. Siddiqui, Y. Zhou, and S. Jiang, Receptor-binding domain of severe acute respiratory syndrome coronavirus spike protein contains multiple conformation-dependent epitopes that induce highly potent neutralizing antibodies, J. Immunol. 174, 4908-4915 (2005).

60. Y. He, Y. Zhou, H. Wu, B. Luo, J. Chen, W. Li, and S. Jiang, Identification of immunodominant sites on the spike protein of severe acute respiratory syndrome (SARS) coronavirus: implication for developing SARS diagnostics and vaccines, J. Immunol. 173, 4050-4057 (2004).

61. K. Kuba, Y. Imai, S. Rao, H. Gao, F. Guo, B. Guan, Y. Huan, P. Yang, Y. Zhang, W. Deng, L. Bao, B. Zhang, G. Liu, Z. Wang, M. Chappell, Y. Liu, D. Zheng, A. Leibbrandt, T. Wada, A. S. Slutsky, D. Liu, C. Qin, C. Jiang, and J. M. Penninger, A crucial role of angiotensin converting enzyme 2 (ACE2) in SARS coronavirus-induced lung injury, Nat. Med. 11, 875-879 (2005).

62. T. Gramberg, H. Hofmann, P. Moller, P. F. Lalor, A. Marzi, M. Geier, M. Krumbiegel, T. Winkler, F. Kirchhoff, D. H. Adams, S. Becker, J. Munch, and S. Pohlmann, LSECtin interacts with filovirus glycoproteins and the spike protein of SARS coronavirus, Virology 340, 224-236 2005.

63. S. A. Jeffers, S. M. Tusell, L. Gillim-Ross, E. M. Hemmila, J. E. Achenbach, G. J. Babcock, W. D. Thomas, Jr., L. B. Thackray, M. D. Young, R. J. Mason, D. M. Ambrosino, D. E. Wentworth, J. C. Demartini, and K. V. Holmes, CD209L (L-SIGN) is a receptor for severe acute respiratory syndrome coronavirus, Proc. Natl. Acad. Sci. USA 101, 15748-15753 (2004).

64. A. Marzi, T. Gramberg, G. Simmons, P. Moller, A. J. Rennekamp, M. Krumbiegel, M. Geier, J. Eisemann, N. Turza, B. Saunier, A. Steinkasserer, S. Becker, P. Bates, H. Hofmann, and S. Pohlmann, DC-SIGN and DC-SIGNR interact with the glycoprotein of Marburg virus and the S protein of severe acute respiratory syndrome coronavirus, J. Virol. 78, 12090-12095 (2004).

65. Z. Y. Yang, Y. Huang, L. Ganesh, K. Leung, W. P. Kong, O. Schwartz, K. Subbarao, and G. J. Nabel, pHdependent entry of severe acute respiratory syndrome coronavirus is mediated by the spike glycoprotein and enhanced by dendritic cell transfer through DC-SIGN, J. Virol. $78,5642-5650$ (2004).

66. M. Donoghue, F. Hsieh, E. Baronas, K. Godbout, M. Gosselin, N. Stagliano, M. Donovan, B. Woolf, K. Robison, R. Jeyaseelan, R. E. Breitbart, and S. Acton, A novel angiotensin-converting enzyme-related carboxypeptidase (ACE2) converts angiotensin I to angiotensin 1-9, Circ. Res. 87, E1-9 (2000).

67. S. R. Tipnis, N. M. Hooper, R. Hyde, E. Karran, G. Christie, and A. J. Turner, A human homolog of angiotensin-converting enzyme. Cloning and functional expression as a captopril-insensitive carboxypeptidase, J. Biol. Chem. 275, 33238-33243 (2000). 
68. C. Vickers, P. Hales, V. Kaushik, L. Dick, J. Gavin, J. Tang, K. Godbout, T. Parsons, E. Baronas, F. Hsieh, S. Acton, M. Patane, A. Nichols, and P. Tummino, Hydrolysis of biological peptides by human angiotensinconverting enzyme-related carboxypeptidase, J. Biol. Chem. 277, 14838-14843 (2002).

69. Y. Yagil and C. Yagil, Hypothesis: ACE2 modulates blood pressure in the mammalian organism, Hypertension 41, 871-873 (2003).

70. M. A. Crackower, R. Sarao, G. Y. Oudit, C. Yagil, I. Kozieradzki, S. E. Scanga, A. J. Oliveira-dos-Santos, J. da Costa, L. Zhang, Y. Pei, J. Scholey, C. M. Ferrario, A. S. Manoukian, M. C. Chappell, P. H. Backx, Y. Yagil, and J. M. Penninger, Angiotensin-converting enzyme 2 is an essential regulator of heart function, Nature 417, 822-828 (2002).

71. Y. Imai, K. Kuba, S. Rao, Y. Huan, F. Guo, B. Guan, P. Yang, R. Sarao, T. Wada, H. Leong-Poi, M. A. Crackower, A. Fukamizu, C. C. Hui, L. Hein, S. Uhlig, A. S. Slutsky, C. Jiang, and J. M. Penninger, Angiotensin-converting enzyme 2 protects from severe acute lung failure, Nature 436, 112-116 (2005).

72. H. Kubo, Y. K. Yamada, and F. Taguchi, Localization of neutralizing epitopes and the receptor-binding site within the amino-terminal 330 amino acids of the murine coronavirus spike protein, J. Virol. 68, 5403-5410 (1994).

73. A. Bonavia, B. D. Zelus, D. E. Wentworth, P. J. Talbot, and K. V. Holmes, Identification of a receptorbinding domain of the spike glycoprotein of human coronavirus HCoV-229E, J. Virol. 77, 2530-2538, (2003).

74. J. J. Breslin, I. Mork, M. K. Smith, L. K. Vogel, E. M. Hemmila, A. Bonavia, P. J. Talbot, H. Sjostrom, O. Noren, and K. V. Holmes, Human coronavirus 229E: receptor binding domain and neutralization by soluble receptor at 37 degrees C, J. Virol. 77, 4435-4438 (2003).

75. G. J. Babcock, D. J. Esshaki, W. D. Thomas, Jr., and D. M. Ambrosino, Amino acids 270 to 510 of the severe acute respiratory syndrome coronavirus spike protein are required for interaction with receptor, $J$. Virol. 78, 4552-4560 (2004).

76. S. K. Wong, W. Li, M. J. Moore, H. Choe, and M. Farzan, A 193-amino acid fragment of the SARS coronavirus S protein efficiently binds angiotensin-converting enzyme 2, J. Biol. Chem. 279, 3197-3201 (2004).

77. X. Xiao, S. Chakraborti, A. S. Dimitrov, K. Gramatikoff, and D. S. Dimitrov, The SARS-CoV S glycoprotein: expression and functional characterization, Biochem. Biophys. Res. Commun. 312, 1159-1164 (2003).

78. F. Li, W. Li, M. Farzan, and S. C. Harrison, Structure of SARS coronavirus spike receptor-binding domain complexed with receptor, Science 309, 1864-1868 (2005).

79. X. X. Qu, P. Hao, X. J. Song, S. M. Jiang, Y. X. Liu, P. G. Wang, X. Rao, H. D. Song, S. Y. Wang, Y. Zuo, A. H. Zheng, M. Luo, H. L. Wang, F. Deng, H. Z. Wang, Z. H. Hu, M. X. Ding, G. P. Zhao, and H. K. Deng, Identification of two critical amino acid residues of the severe acute respiratory syndrome coronavirus spike protein for its variation in zoonotic tropism transition via a double substitution strategy, $J$. Biol. Chem. 280, 29588-29595 (2005).

80. Z. Y. Yang, H. C. Werner, W. P. Kong, K. Leung, E. Traggiai, A. Lanzavecchia, and G. J. Nabel, Evasion of antibody neutralization in emerging severe acute respiratory syndrome coronaviruses, Proc. Natl. Acad. Sci. USA 102, 797-801 (2005).

81. M. A. Marra, S. J. Jones, C. R. Astell, R. A. Holt, A. Brooks-Wilson, Y. S. Butterfield, J. Khattra, J. K Asano, S. A. Barber, S. Y. Chan, A. Cloutier, S. M. Coughlin, D. Freeman, N. Girn, O. L. Griffith, S.R. Leach, M. Mayo, H. McDonald, S. B. Montgomery, P. K. Pandoh, A. S. Petrescu, A. G. Robertson, J. E. Schein, A. Siddiqui, D. E. Smailus, J. M. Stott, G. S. Yang, F. Plummer, A. Andonov, H. Artsob, N. Bastien, K. Bernard, T. F. Booth, D. Bowness, M. Czub, M. Drebot, L. Fernando, R. Flick, M. Garbutt, M. Gray, A. Grolla, S. Jones, H. Feldmann, A. Meyers, A. Kabani, Y. Li, S. Normand, U. Stroher, G. A Tipples, S. Tyler, R. Vogrig, D. Ward, B. Watson, R. C. Brunham, M. Krajden, M. Petric, D. M. Skowronski, C. Upton, and R. L. Roper, The genome sequence of the SARS-associated coronavirus, Science 300, 1399-1404 (2003).

82. J. F. He, G. W. Peng, J. Min, D. W. Yu, W. J. Liang, S. Y. Zhang, R. H. Xu, H. Y. Zheng, X. W. Wu, J. Xu, Z. H. Wang, L. Fang, X. Zhang, H. Li, X. G. Yan, J. H. Lu, Z. H. Hu, J. C. Huang, and X. W. Wan, Molecular evolution of the SARS coronavirus during the course of the SARS epidemic in China, Science 303, 1666-1669 (2004) 